\title{
Cell Type-Specific Sorting of Neuropeptides: A Mechanism to Modulate Peptide Composition of Large Dense-Core Vesicles
}

\author{
Judith Klumperman, Sabine Spijker, Jan van Minnen, Hilary Sharp-Baker, August B. Smit, and \\ Wijnand P. M. Geraerts \\ Graduate School Neurosciences Amsterdam, Research Institute Neurosciences Vrije Universiteit, Faculty of Biology, 1081 \\ HV Amsterdam, The Netherlands
}

The CNS of Lymnaea stagnalis contains two populations of egg-laying hormone (ELH)-producing neurons that differ in size and topology. In type I neurons, all peptides located C-terminally from the cleavage site Arg-Ser-Arg-Arg ${ }^{180-183}$ are sorted into secretory large dense-core vesicles (LDCV), whereas $\mathrm{N}$-terminal-located peptides accumulate in a distinct type of vesicle, the large electrondense granule (LEG). Via immunoelectron microscopy, we now show that the second population of ELH-producing neurons, type II neurons, lack LEG and incorporate all proELH-derived peptides into LDCV. This finding provides the first example of a cell type-specific sorting of neuropeptides into LDCV. Furthermore, we provide evidence that LEG are formed through a differential condensation process in the trans-Golgi network and that these bodies are ultimately degraded. Analysis of the endoprotease composition of the two types of proELH-producing neurons suggests that the formation of LEG, and consequently the retention of $\mathrm{N}$-terminal peptides from the secretory pathway, requires the action of a furin-like protein.

Key words: sorting; neuropeptides; LDCV; Lymnaea; immunoelectron microscopy; furin; egg laying; processing
Neuropeptides are synthesized at the rough endoplasmic reticulum, traverse the Golgi complex, and are incorporated into large dense-core vesicles (LDCV). The subsequent targeting of LDCV to distant release sites and their exocytosis in response to specific stimuli define the pathway of regulated secretion (for review, see Kelly, 1993). Many neuropeptides are synthesized as larger precursor proteins (prohormones) that must be post-translationally cleaved and modified to generate bioactive peptides. Endoproteolytic processing occurs by a group of highly conserved kexin/ subtilisin-like endoproteases, which are either membrane-bound or soluble proteins (Steiner, 1991).

The distinct processing steps during the biosynthesis of neuropeptides as well as the sorting of defined sets of neuropeptides into LDCV offers peptidergic neurons the unique opportunity to regulate the composition of peptides that they release. A well studied example in this respect is the egg laying hormone (ELH) of Aplysia californica and Lymnaea stagnalis. Scheller and colleagues recognized that proELH in Aplysia in the Golgi complex is cleaved into two processing intermediates, after which these intermediates are differentially distributed over two classes of LDCV (Kreiner et al., 1986; Fisher et al., 1988), which are targeted to distinct release sites (Sossin et al., 1990a). Notably, a majority of N-terminal-derived peptides were found to be packaged into a third population of vesicles (Fischer et al., 1988; Sossin et al., 1990b) that differed from LDCV and will be further indicated as large electron-dense granule (LEG). Analogous to Aplysia, immunoelectron microscopy and mass spectrometry have

\footnotetext{
Received July 17, 1996; revised Sept. 24, 1996; accepted Oct. 1, 1996.
}

We thank T. Broers-Vendrig for technical assistance, and we acknowledge Prof. H. J. Geuze (University of Utrecht, The Netherlands) for his critical comments on this manuscript.

Correspondence should be addressed to Dr. Judith Klumperman, Vrije Universiteit, Faculty of Biology, De Boelelaan 1087, 1081 HV Amsterdam, The Netherlands.

Copyright (C) 1996 Society for Neuroscience $0270-6474 / 96 / 167930-11 \$ 05.00 / 0$ shown that also in the so-called type I neurons of Lymnaea (the main site of proELH synthesis) the peptides derived from the C-terminal part of proELH are efficiently sorted into LDCV (van Heumen and Roubos, 1991; Li et al., 1994), whereas the $\mathrm{N}$-terminal peptides are incorporated into LEG.

LEG reside in the cell body and have never been found to fuse with the plasma membrane (Kreiner et al., 1984; Fischer et al., 1988; Sossin et al., 1990b; van Heumen and Roubos, 1991). The concentration of peptides derived from the C-terminal part of proELH is severalfold higher than the concentration of N-terminal peptides (Fischer et al., 1988; Li et al., 1994), and in Lymnaea the number of LEG does not increase in old animals ( $\mathrm{J}$. Klumperman, unpublished data). Together, the data suggest that LEG are destined to be degraded, which implies a systematic removal of a specific subset of proELH-derived products.

In the present study, we have investigated the distribution of $\mathrm{N}$ and C-terminal peptides in the two populations, type I and type II (Van Minnen et al., 1988), of proELH-producing neurons in the CNS of Lymnaea. We have found that type II neurons lack LEG and sort both $\mathrm{N}$ - and $\mathrm{C}$-terminal peptides into LDCV. This observation provides the first example of cell type-specific sorting of neuropeptides into the secretory pathway and suggests a role of LEG in tuning the composition of secretory neuropeptides.

\section{MATERIALS AND METHODS}

Ultrathin cryosectioning. All studies were performed on adult specimens of Lymnaea, shell-height $25-30 \mathrm{~mm}$, which were raised under standard conditions. The two cerebral ganglia and their connecting commissure were removed from the CNS as a whole and fixed for $2 \mathrm{hr}$ in $2 \%$ formaldehyde and $0.2 \%$ glutaraldehyde in $0.1 \mathrm{M}$ phosphate buffer, $\mathrm{pH} 7.4$, at room temperature. Then the two ganglia and the commissure were cut into three separate pieces, which were embedded in $10 \%$ gelatin in PBS. The gelatin blocks were impregnated with $2.3 \mathrm{M}$ sucrose and further prepared for cryosectioning as described previously (Slot et al., 1988). Isolated cerebral ganglia were mounted to a specimen holder in such a way that both groups of neurons were in the plane perpendicular to the 
section edge. Then $1 \mu \mathrm{m}$ sections were prepared and labeled with anti-ELH and a FITC-conjugated secondary antibody (data not shown). If in these semithick sections both type I and type II neurons were detected, thin sections were prepared and immunogold-labeled. Multiple immunogold labeling was performed as described previously (Slot et al., 1991), after which the grids were analyzed in a Philips EM300 electron microscope.

Araldite embedding and acid phosphatase cytochemistry. Cerebral ganglia were fixed overnight in $0.5 \%$ glutaraldehyde in $0.01 \mathrm{M} \mathrm{Na}$ -

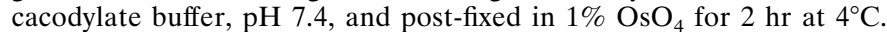
Embedding in araldite, etching, and immunogold labeling were performed as described previously (van Heumen and Roubos, 1991). Acid phosphatase cytochemistry was performed essentially as described by Barka and Anderson (1962).

Antibodies. To immunolocalize the Lymnaea ELH, we used a mouse monoclonal antibody raised against a synthetic peptide representing amino acids $21-36$ of the ELH peptide. The antibody only recognizes free peptide (van Heumen and Roubos, 1991). As a marker for the peptides located N-terminally from the first cleavage site Arg-Ser-Arg-Arg ${ }^{180-183}$ (Li et al., 1994), we used an affinity-purified polyclonal rabbit antibody against the $\mathrm{N}$-terminal $\alpha$-caudodorsal peptide $(\alpha \mathrm{CDCP})$ (van Heumen and Roubos, 1991). This antibody also reacts with $\alpha \mathrm{CDCP}$ in proELH. $\alpha \mathrm{CDCP}$ has the same subcellular distribution pattern as the $\mathrm{N}$-terminal peptides calfluxin and $\beta$-peptide (van Heumen et al., 1992) (J. Klumperman, unpublished data). For clarity, therefore, we will refer to this antibody as anti-N-terminal peptide.

Quantitative analysis of immunogold labeling. During our studies, distinct gold sizes were used and the sequence of antibodies was alternated. This had no influence on the overall distribution of ELH and N-terminal peptide. Quantitations, however, were always performed on sections labeled first with anti-ELH and $10 \mathrm{~nm}$ gold particles, and then with anti-N-terminal peptide and $15 \mathrm{~nm}$ gold particles. For each animal, all sections used for quantitation were prepared simultaneously using the same reagents. The ELH and N-terminal peptide stainings were taken as relative labeling densities by calculating the number of gold particles obtained in double-immunolabeled cryosections. By establishing these relative densities, putative differences in labeling intensity attributable to, e.g., accessibility were prevented. The ratios were divided into 10 classes (values between 0 and $0.24,0.25$ and $0.34,0.35$ and 0.44 , etc.) and converted into frequency plots.

To calculate the ratio of $\mathrm{N}$ - and $\mathrm{C}$-terminal proELH-derived peptides in the LDCV of type I neurons, we took electron micrographs of the cell body; at the release sites, we took electron micrographs of the collaterals and the axon endings. The grids were first scanned at low magnification, and the areas to be photographed were selected on basis of a good overall morphology. For quantitation, three snails were used. Five type I cell bodies were analyzed per snail. Three pictures were taken of each cell body. Also, five axon endings were photographed. Because of the low number of LDCV in the collaterals, all collaterals present in a cross section of the commissure were photographed. Finally, five clusters of axonal type II LDCV were photographed per animal.

Probe synthesis. To study the endoprotease composition of type I and type II neurons, specific $\left[\alpha-{ }^{35} \mathrm{~S}\right] \mathrm{UTP}-$ labeled cRNA probes (DuPont NEN) were made on $200 \mathrm{ng}$ of linearized cDNA of Lymnaea prohormone convertase 2 (LPC2; nt 1521-2632) (Smit et al., 1992), Lymnaea furin 1 (Lfur1; nt 1578-2067), and Lymnaea furin 2 (Lfur2; nt 1341-2392) (Smit et al., 1992, 1994), including the $T_{3}$ and $T_{7}$ polymerase promotores. Separate in vitro transcription reactions were performed at $37^{\circ} \mathrm{C}$, using either $T_{3}$ or $T_{7}$ RNA polymerase (Boehringer Mannheim) containing 1 $\mathrm{mM} \mathrm{G} / \mathrm{A} / \mathrm{CTP}$ and $3 \mu \mathrm{M}\left[\alpha^{-}{ }^{35} \mathrm{~S}\right] \mathrm{UTP}$. After $2 \mathrm{hr}$, the reactions were stopped and the cDNA templates were removed with $10 \mathrm{U}$ of RNase-free DNase (Boehringer Mannheim) at $37^{\circ} \mathrm{C}$ during $10 \mathrm{~min}$. The probes were hydrolyzed for $30 \mathrm{~min}$ on ice in $0.2 \mathrm{M} \mathrm{NaOH}, 0.6 \mathrm{~mm}$ EDTA, $0.06 \%$ SDS, $100 \mathrm{~nm} \mathrm{NaCl}$, and $12 \mathrm{~mm}$ DTT in $6 \mathrm{~mm}$ Tris- $\mathrm{HCl}, \mathrm{pH}$ 7.5, and at room temperature they were neutralized with $0.2 \mathrm{M}$ MES buffer $[(2 \mathrm{CN}$ morpholino)ethanesulfonic acid; Sigma] and ethanol-precipitated. Both antisense and sense (control) cRNA probes have specific activities between $1 \times 10^{7}$ and $1 \times 10^{8} \mathrm{cpm} / \mu \mathrm{g}$ RNA.

In situ hybridization and immunocytochemistry. Serial $7 \mu \mathrm{m}$ sections of $1 \%$ paraformaldehyde $/ 1 \%$ acetic acid-fixed CNS were used for in situ hybridization. After pretreating the slides as described by Smit et al. (1996), the sections were prehybridized for $1 \mathrm{hr}$ with hybridization mixture $(60 \%$ deionized formamide, $5 \times \mathrm{SCC}(1 \times \mathrm{SCC}, 150 \mathrm{~mm} \mathrm{NaCl}, 15 \mathrm{~mm}$ sodium citrate, $\mathrm{pH} 7.0), 5 \times$ Denhardt's solution $(1 \times$ Denhardt's; $0.02 \%$ bovine serum albumin, $0.02 \%$ Ficoll, $0.02 \%$ polyvinylpyrolidon), 200

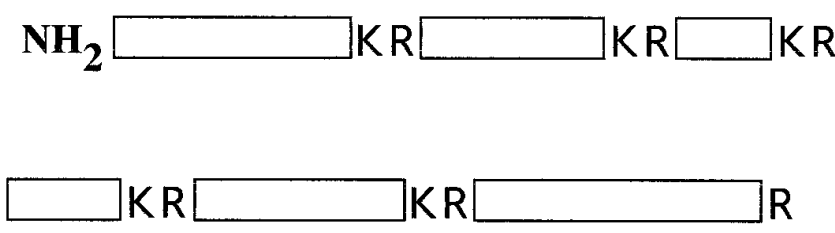

N-terminal peptide RKR $\square$ RSRR

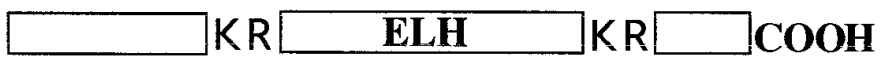

Figure 1. Schematic representation of Lymnaea proELH in which all basic cleavage sites are indicated. Endoproteolytic cleavage on these sites results in the formation of 11 peptides. The arrow points to the first cleavage site, Arg-Ser-Arg-Arg ${ }^{180-183}$, that is used in the Golgi of type I neurons (Li et al., 1994). In this study, we used antibodies against $\mathrm{N}$-terminal peptide and ELH to study the targeting of peptides that are located N- or C-terminally from this site.

$\mu \mathrm{m} / \mathrm{ml}$ acid/alkali-cleaved herring sperm DNA, $25 \mathrm{~mm}$ Na-phosphate buffer $\left(25 \mathrm{mM} \mathrm{Na}_{2} \mathrm{HPO}_{4}, 25 \mathrm{mM} \mathrm{NaH}_{2} \mathrm{PO}_{4}, \mathrm{pH} 7.0\right)$, and $10 \%$ dextrane sulfate. Hybridization was carried out overnight at $50^{\circ} \mathrm{C}$ by applying ${ }^{35} \mathrm{~S}$-labeled probe at a final activity of $1.5 \times 10^{6} \mathrm{cpm}$ per slide. Then the slides were rinsed to a stringency of $2 \times \mathrm{SSC} / 50 \%$ formamide at $50^{\circ} \mathrm{C}$ according to Smit et al. (1996). For the subsequent immunolabeling, grids were incubated in TBS-gelatin buffer $(0.1 \mathrm{~m}$ Tris $/ \mathrm{HCl}, 0.05 \%$ Tween 20 , $0.25 \%$ gelatin, $\mathrm{pH} 7.4)$. The slides were then immunolabeled for ELH using the procedure described by van Minnen et al. (1988). Finally, radioactivity was visualized by dipping the slides in melted, diluted (1:3) Ilford $\mathrm{K}_{5}$ emulsion. After air drying, the sections were exposed for 5-10 $\mathrm{d}$ in the dark at $4^{\circ} \mathrm{C}$. The autoradiographs were developed $(2 \mathrm{~min})$ in Kodak $\mathrm{D}_{19}$ developer, fixed $(3 \mathrm{~min})$ in $24 \%$ sodium thiosulphate and Ilford rapid fixative (5 min), and rinsed in flowing tap water for $30 \mathrm{~min}$. After dehydration in graded ethanols and clearance in xylene, the coverslips were mounted with Entallan.

\section{RESULTS}

\section{The two populations of proELH-producing neurons incorporate distinct amounts of $\mathrm{N}$-terminal peptide into LDCV}

In the Lymnaea CNS, two types of proELH-producing neurons are present, which will be indicated further as type I and type II neurons (van Minnen et al., 1988). Type I neurons form LEG (Van Heumen and Roubos, 1991) harboring the majority of proELH-derived peptides located $\mathrm{N}$-terminal of the first cleavage site Arg-Ser-Arg-Arg ${ }^{180-183}$ (Fig. 1). Their LDCV are transported to two release sites: (1) the axon endings, from which release into the circulation occurs, and (2) the collaterals, from which release into the intracellular space is mediated (Schmidt and Roubos, 1989). Type II neurons are small and constitute a minor population of cells that are located laterally in the cerebral ganglia with their axons projecting inward (van Minnen et al., 1988).

To discriminate unequivocally between type I and type II neurons at the ultrastructural level, we studied sections with both types present. An example of the selective concentration of $\mathrm{N}$-terminal peptide in LEG is given in Figure $2 A$, in which ELH and N-terminal peptide were simultaneously localized in an ultrathin cryosection of a type I neuron. To get a detailed insight into the sorting of proELH-derived peptides into the LDCV of type I neurons, the ratio ELH/(ELH + N-terminal peptide) in type I LDCV was calculated in the cell body and at the two release sites (Fig. $2 B, C$ ). It was found that the ratio of the LDCV in the cell 

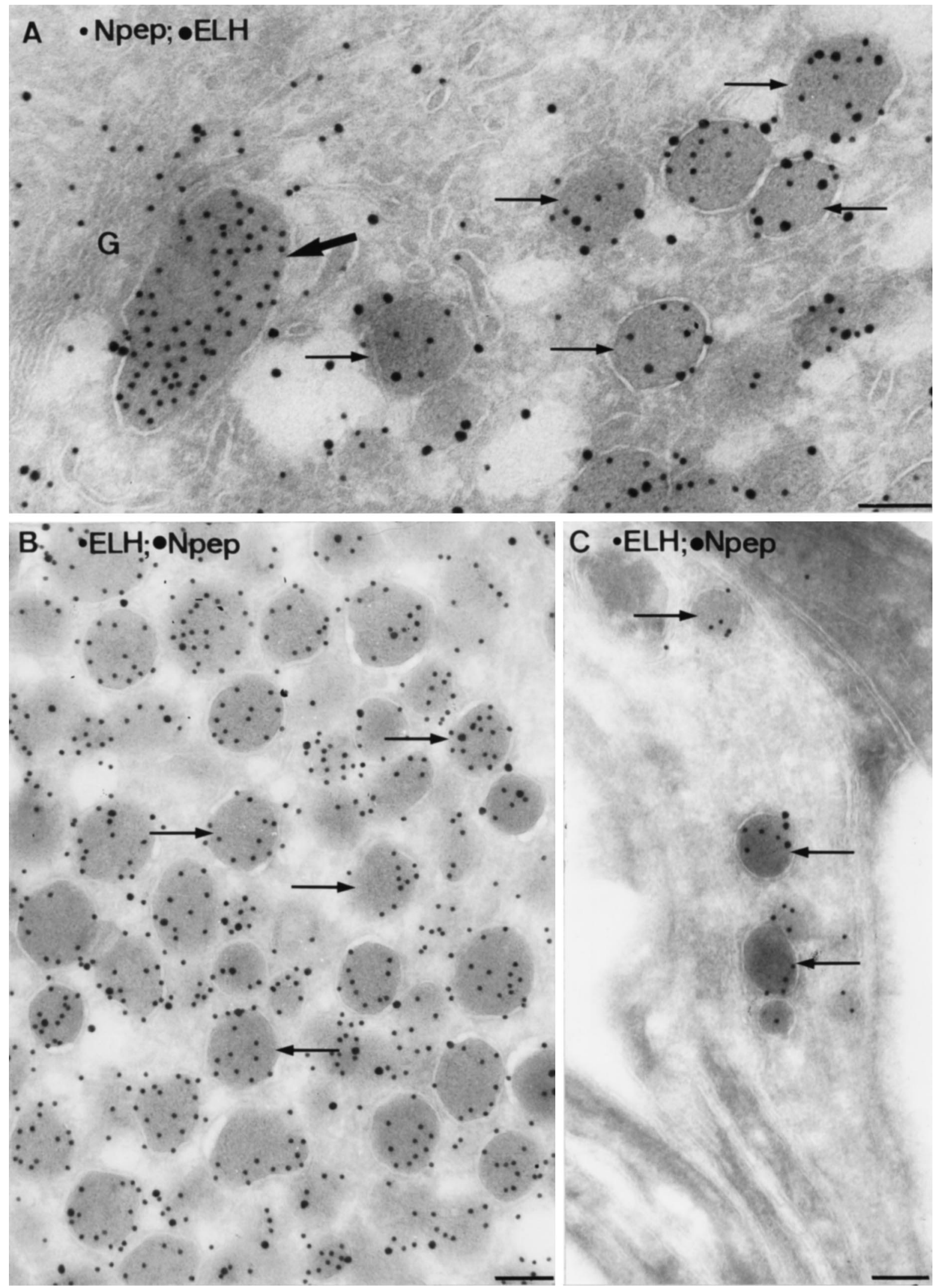

Figure 2. Ultrathin cryosections of type I neurons double-immunolabeled for N-terminal peptide and ELH. LDCV (arrows) were present in the cell body $(A)$, in the axon endings $(B)$, and in the collaterals $(C)$. LEG (bold arrow in $A$ ) were only present in the cell body. Note the absence of ELH label in the LEG. $G$, Golgi. Scale bars, $0.1 \mu \mathrm{m}$. 


\begin{tabular}{|c|c|c|c|c|c|c|}
\hline \multirow[b]{2}{*}{ LDCV } & \multicolumn{2}{|l|}{1} & \multicolumn{2}{|l|}{2} & \multicolumn{2}{|l|}{3} \\
\hline & Ratio \pm SEM & $n$ & Ratio \pm SEM & $n$ & Ratio \pm SEM & $n$ \\
\hline Type I: cell body & $0.9 \pm 0.009$ & 315 & $0.85 \pm 0.03$ & 674 & $0.79 \pm 0.03$ & 642 \\
\hline Type I: collateral & $0.9 \pm 0.02$ & 63 & $0.89 \pm 0.02$ & 67 & $0.79 \pm 0.03$ & 100 \\
\hline Type II & $0.66 \pm 0.02$ & 110 & $0.41 \pm 0.03$ & 69 & $0.24 \pm 0.03$ & 62 \\
\hline
\end{tabular}

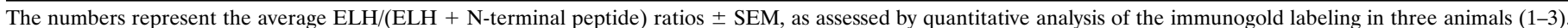

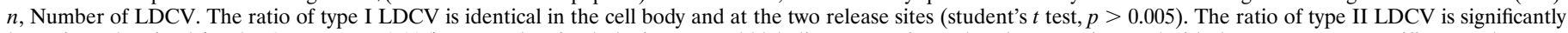

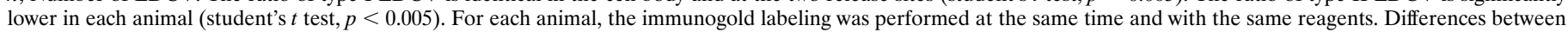
the animals may be attributable to variations in labeling efficiency and, therefore, may not be compared.

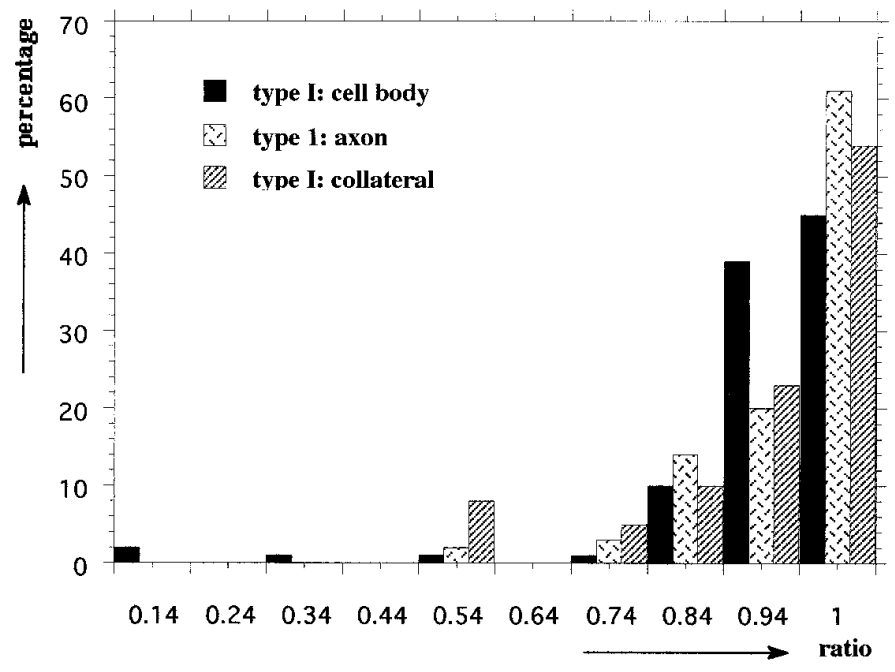

Figure 3. Frequency diagram of the ELH/(ELH + N-terminal peptide) ratios, as assessed in type I LDCV of animal 1. From this diagram, it is apparent that all type I LDCV belong to a single population.

body was identical to the ratio of the LDCV in the axon endings as well as to the LDCV present in the collaterals (Student's $t$ test, $p>0.005$; Table 1). When the quantitative data of a particular animal were plotted into a frequency diagram, an example of which is shown in Figure 3, it was apparent that type I neurons contain a single population of LDCV. Interestingly, a similar approach in Aplysia has revealed the existence of two populations of ELH containing LDCV that differ in their relative peptide content and are transported to distinct release sites (Sossin et al., 1990a). Our data show that in Lymnaea type I neurons no such sorting occurs.

The LDCV in type II neurons (Fig. $4 C, D$ ) were smaller in size than in type I neurons ( 90 and $150 \mathrm{~nm}$, respectively) and appeared to be more heavily labeled for N-terminal peptide than type I LDCV. Similar LDCV were regularly observed at some distance of the cell body, but never at sites from which release to the circulation could occur. We will refer to these $90 \mathrm{~nm}$ LDCVs as type II LDCV to discriminate them from the type I LDCV as found in type I neurons. In type II neurons, LEG were absent.

In the Golgi area of type II neurons, the ELH staining was weak (Fig. $4 A, B)$ compared to more peripherally and axonally located LDCV (Fig. $4 C, D$ ). A possible explanation for this heterogeneous labeling density is that the anti-ELH antibody does not recognize the unprocessed peptide (van Heumen and Roubos, 1991). The observed labeling pattern, therefore, most likely reflects different stages of processing of proELH. Having noticed this, we only used axonally located type II LDCV (Fig. 4D) for subsequent quantitative studies. When the $\mathrm{ELH} /(\mathrm{ELH}+\mathrm{N}$-terminal peptide $)$ ratios of type I and II LDCV of a particular animal were compared, the ratio of type II LDCV was found to be significantly (Student's $t$ test, $p<0.005$ at all times) lower than the ratio of type I LDCV (Table 1). The low ratio of type II LDCV was mainly caused by a relatively high labeling of the $\mathrm{N}$-terminal peptide (on average 4.27-fold higher than in the type I LDCV). When all data from a particular animal were transferred into a frequency diagram, an example of which is shown in Figure 5, it was found that the type I and II LDCV constitute two distinct populations, with only partially overlapping ratios.

Taken together, these data show that the two proELHproducing neuron types in the Lymnaea CNS sort different sets of proELH-derived peptides into their LDCV. The incorporation of low amounts of N-terminal peptide into the LDCV coincides with the presence of LEG.

\section{LEG are formed by a differential condensation/sorting event}

The formation of LDCV and LEG within a particular cell must be preceded by a tightly regulated sorting mechanism. To gain insight into this process, we performed a detailed immunoelectron microscopic analysis of the Golgi complex and trans-Golgi network (TGN) of type I neurons. Condensed proteins of homogeneous electron density were observed throughout the Golgi stacks but, in particular, in the distended rims of almost all cisternae (Figs. $6 A, B, 7 A)$. In the trans-most Golgi cisterna and TGN, condensed protein cores were found with distinct electron densities (Fig. $6 A, B)$. The lighter portion had a density identical to LDCV and labeled predominantly for ELH (Fig. 6A), whereas the darker portion had a density identical to LEG and was mainly positive for $\mathrm{N}$-terminal peptide (Fig. 6B). Membranes harboring the differentially condensed material often formed buds with an electrondense cytosolic coat, morphologically identical to clathrin (Fig. $6 A$ ). Within the TGN, areas were found in which protein precipitates with similar or distinct content were spatially segregated within a continuous membrane (Fig. $6 C, D$ ), suggesting that LEG, like LDCV, can be formed by budding from the TGN.

To illustrate the degradative nature of LEG, we combined acid phosphatase cytochemistry with the immunogold labeling technique. Figure 7 shows the colocalization of lysosomal acid phosphatase and N-terminal peptide in LEG. In both the Golgi area (Fig. 7A) and more peripheral (Fig. 7B,C), acid phosphatasepositive LEG were observed. Occasionally, the N-terminal peptide reactivity was markedly reduced in the peripheral acid phosphatase-positive LEG (Fig. 7C). Additional acid phosphatase reactivity was observed, as expected, in the trans-Golgi, TGN, and lysosomes (data not shown). 

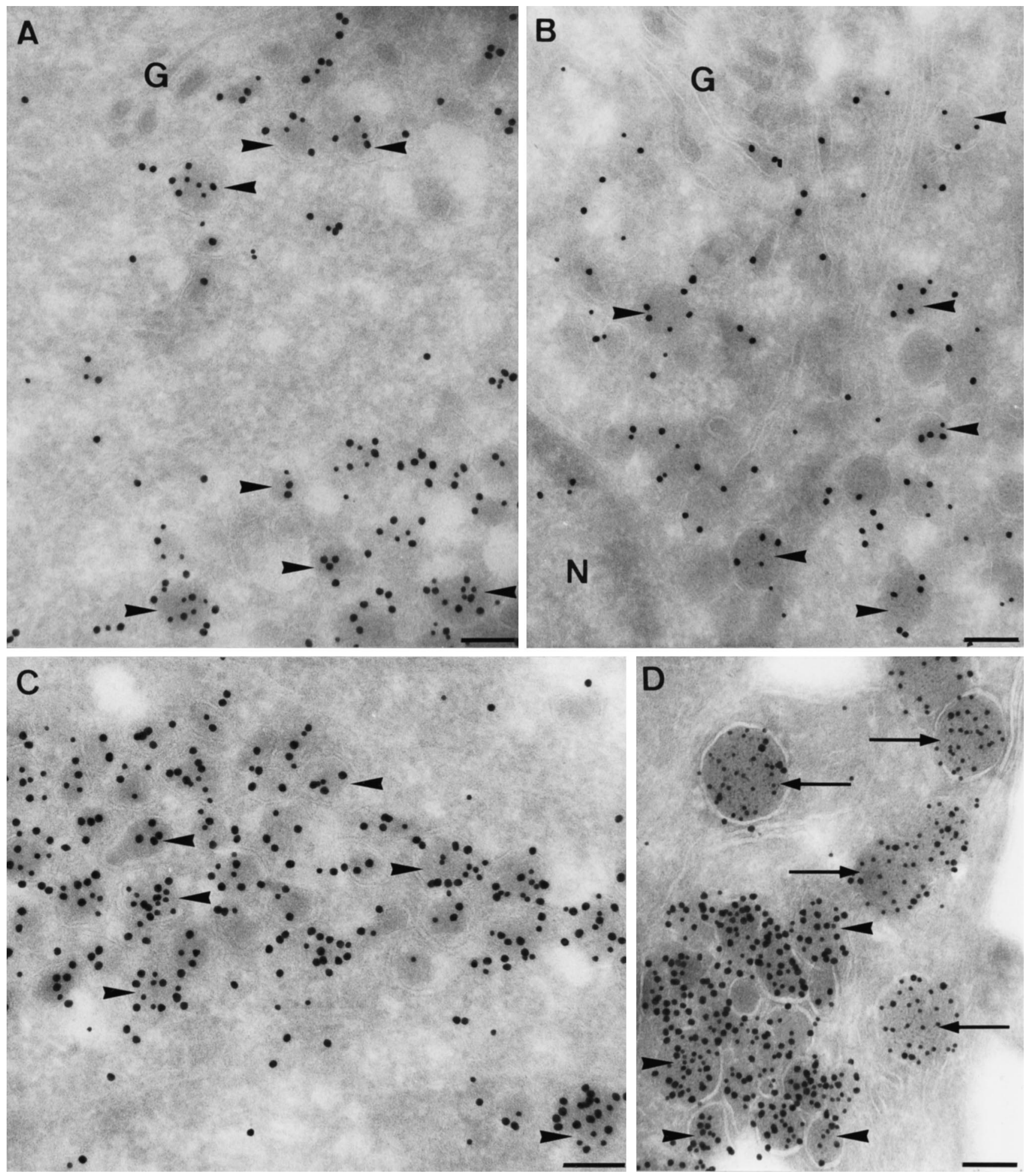

Figure 4. Ultrathin cryosections of type II neurons double-immunolabeled for ELH (small gold particles) and N-terminal peptide (large gold particles). Type I LDCV (arrowheads) were present in the Golgi $(G)$ region $(A, B)$, in clusters in the cell body $(C)$, and in the axons $(D)$. LEG were absent. Note that the intensity of ELH staining is highest in the axon $(D)$. In $D$, a type II axon is closely opposed to a type I axon. A few type I LDCV are visible (arrows), which are larger and less intensely labeled for N-terminal peptide. $N$, Nucleus. Scale bars, $0.1 \mu \mathrm{m}$.

These observations show that proteins destined for either LEG or LDCV are segregated via a differential condensation process in the trans-Golgi and TGN. LEG acquire lysosomal enzymes via an as yet unidentified pathway.

\section{Expression of Lfur1, Lfur2, and LPC2 by type I and type II neurons}

A prerequisite for the formation of both LDCV and LEG in type I neurons is the proteolytic cleavage of proELH at site Arg-Ser- 


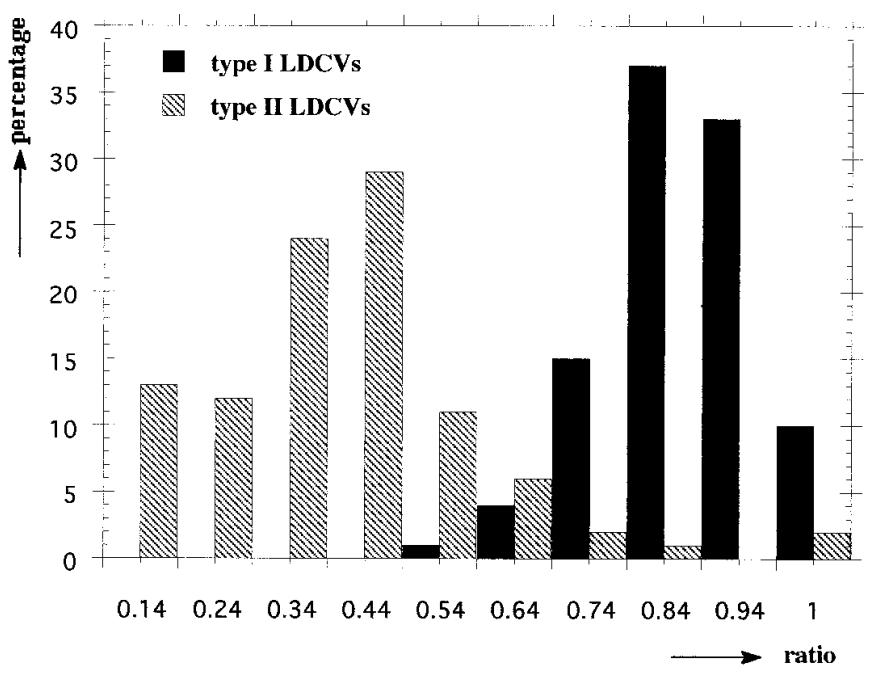

Figure 5. Frequency diagram of the ELH/(ELH + N-terminal peptide) ratios, as assessed in type I and type II LDCV of animal 1. From this diagram, it is apparent that type I and type II LDCV form two subpopulations with only partially overlapping ratios.

Arg-Arg ${ }^{180-183}$ and the subsequent segregation of the two intermediates. A possible explanation for the observation that in type II neurons this sorting step does not occur would be that in these neurons no early cleavage step is performed (see model in Fig. 8). Endoproteolytic cleavage of tetrabasic sites in the TGN is mediated by the membrane-bound subtilisin-like furins (Bresnahan et al., 1990; Hosaka et al., 1990; Van de Ven et al., 1990; Wise et al., 1990; Korner et al., 1991b; Bosshart et al., 1994; Molloy et al., 1994). In a previous study, it was established that in the Lymnaea CNS two proteins are expressed with high homology to furin: Lfur1 and Lfur2. In addition, a third endoprotease was identified with $80 \%$ sequence homology to soluble vertebrate prohormone convertase 2: LPC2 (Smit et al., 1992, 1994). To gain insight into the putative involvement of these endoproteases in proELH processing, their expression in type I and II neurons was investigated using a radioactive in situ hybridization approach, combined with the immunocytochemical detection of ELH.

The mRNAs encoding the three endoproteases were readily detectable and showed heterogeneous distribution patterns (Fig. 9). Signal for Lfur1 was obtained in neurons not expressing proELH, but was below detection level in both type I and type II neurons (Fig. 9A,B). By contrast, significant levels of LPC2 mRNA were found in both of the ELH-producing neuron types (Fig. 9G,H). Most interestingly, we found a high level of Lfur2 expression in type I neurons, whereas no signal could be detected in the type II neurons (Fig. $9 C-F$ ).

\section{DISCUSSION}

In this paper, we show that two types of proELH-producing neurons in the Lymnaea CNS incorporate distinct sets of peptides into their LDCV. This finding provides the first example of a cell type-specific sorting of prohormone-derived peptides into the secretory pathway. In the case of pro-opiomelanocortin, alternate proteolytic processing has been revealed as a mechanism to express distinct, yet related, peptides in different tissues (Benjannet et al., 1991). Another mechanism to post-translationally vary the output of a secretory cell is when distinct neuropeptides are sorted to different LDCV, e.g., Aplysia-ELH (Kreiner et al., 1986; Fischer et al., 1988) and prolactin and growth hormone in somato- mammotrophs (Fumagalli and Zanini, 1985; Hashimoto et al., 1987). With our observation that type II neurons package all proELH-derived peptides into LDCV, whereas type I neurons degrade a subset of these peptides in LEG, we describe an additional regulatory mechanism. A key event in this process is the formation of LEG. Circumstantial evidence has suggested that LEG are degradative structures (see introductory remarks). Earlier attempts to localize lysosomal enzymes in LEG, however, were conflicting (Kreiner et al., 1989; Sossin et al., 1990b) or lacked immunocytochemical identification of the granules (Roubos, 1976). In a combined immunocytochemical and enzyme cytochemical approach, we have now shown that LEG contain lysosomal acid phosphatase and that the amount of N-terminal peptide present in acid phosphatase-positive LEG is low. This finding establishes LEG as degradative compartments.

It remains to be shown how LEG are degraded. In the Aplysia bag cells, combined enzyme cytochemistry and autoradiography showed that acid phosphatase is removed from LEG that are still part of the TGN (Sossin et al., 1990). Concomitantly, the number of LEG that was found positive for acid phosphatase was only low (Sossin et al., 1990) (this paper), suggesting that the acquisition of degradative enzymes occurs after maturation of the granule. It remains possible, however, that acid phosphatase activity is more difficult to detect in tightly packed mature granules. Possibly, the onset of degradation of LEG depends on the electrical stage of the cells; preliminary data in our laboratory have suggested that the number of LEG varies during an activation cycle of type I neurons. It has been long established that when secretory cells produce more proteins than they secrete, LDCV are degraded by fusion with a lysosome (crinophagy) (Farquhar et al., 1969; Marzella and Glaumann, 1987). Alternatively, organelles may be degraded by autophagy (Dunn, 1987). Both pathways could account for the degradation of LEG, whereby the identification and recognition of LEG as degradable compartments are prerequisite.

We have also shown that the formation of LEG and LDCV is preceded by a differential condensation of the $\mathrm{N}$ - and C-terminal intermediates in the trans-Golgi/TGN. Within the TGN, condensed cores containing either $\mathrm{N}$ - or $\mathrm{C}$-terminal proteins are spatially separated, suggesting that LEG, like LDCV, can arise from the TGN. In addition, protein cores of distinct content may well be incorporated together into immature LDCV. Analogous to other systems in which immature LDCV have been proposed to be involved in protein sorting (Garreau de Loubresse et al., 1994; Gautier et al., 1994; Kuliawat and Arvan, 1994; Huang and Arvan, 1994, 1995), LEG could also arise from immature LDCV.

Condensation of proteins is regarded as a selective sorting mechanism that excludes other proteins not destined for the regulatory secretory route (for review, see Tooze et al., 1993). The formation of LEG in type I neurons, however, suggests that condensation of N-terminal peptides by itself does not lead to incorporation into LDCV. Protein condensation as a mechanism to prevent proteins from entering the secretory pathway has only been described in myeloma cells overexpressing mutant immunoglobulin and in stimulated exocrine pancreatic cells (formation of Russell bodies and intracisternal granules, respectively) (Tooze et al., 1989; Valetti et al., 1991). Under these conditions, condensation has already occurred in the RER, and in the case of the intracisternal granules, the condensed proteins were eventually degraded via autophagy (Tooze et al., 1989). Soluble proteins without a specific sorting signal exit the TGN in small vesicles that constitutively fuse with the plasma membrane. The type I neurons may use the condensation of the N-terminal intermediates and 

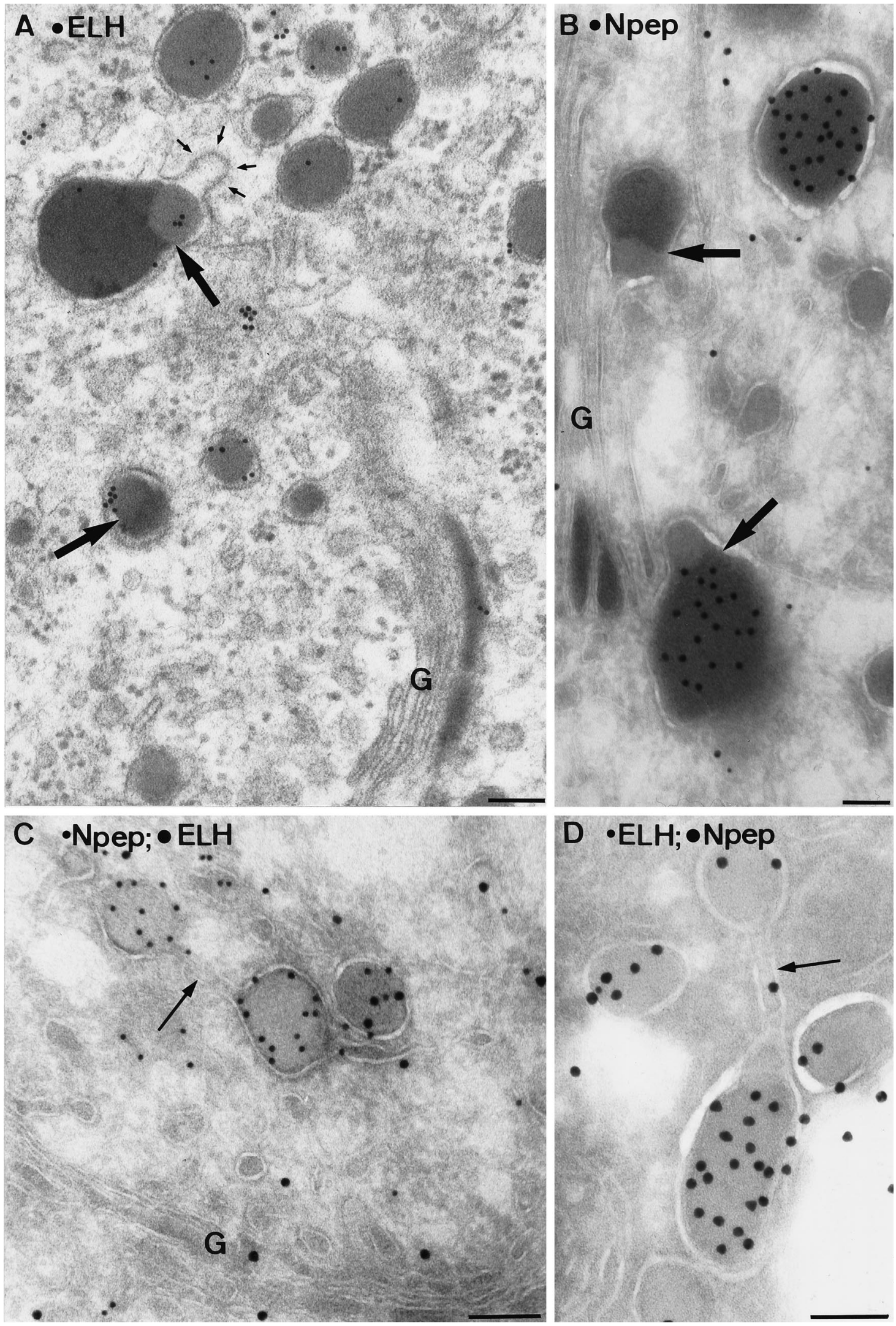

Figure 6. Electron micrographs of a plastic section $(A)$ and ultrathin cryosections $(B-D)$ of the TGN of type I neurons. Within condensing vacuoles at the trans-Golgi $(B)$ and at various sites in the TGN $(A)$, condensed protein cores with distinct electron densities are found (bold arrows). The lighter part labels for ELH $(A)$, and the darker portion labels for $\mathrm{N}$-terminal peptide $(B)$. The membranes surrounding these differentially condensed proteins may form coated buds (small arrows in $A$ ). Sometimes protein cores with similar $(C)$ or distinct $(D)$ protein contents were segregated within the continuous membrane of the TGN (arrows). Scale bars, $0.1 \mu \mathrm{m}$. 

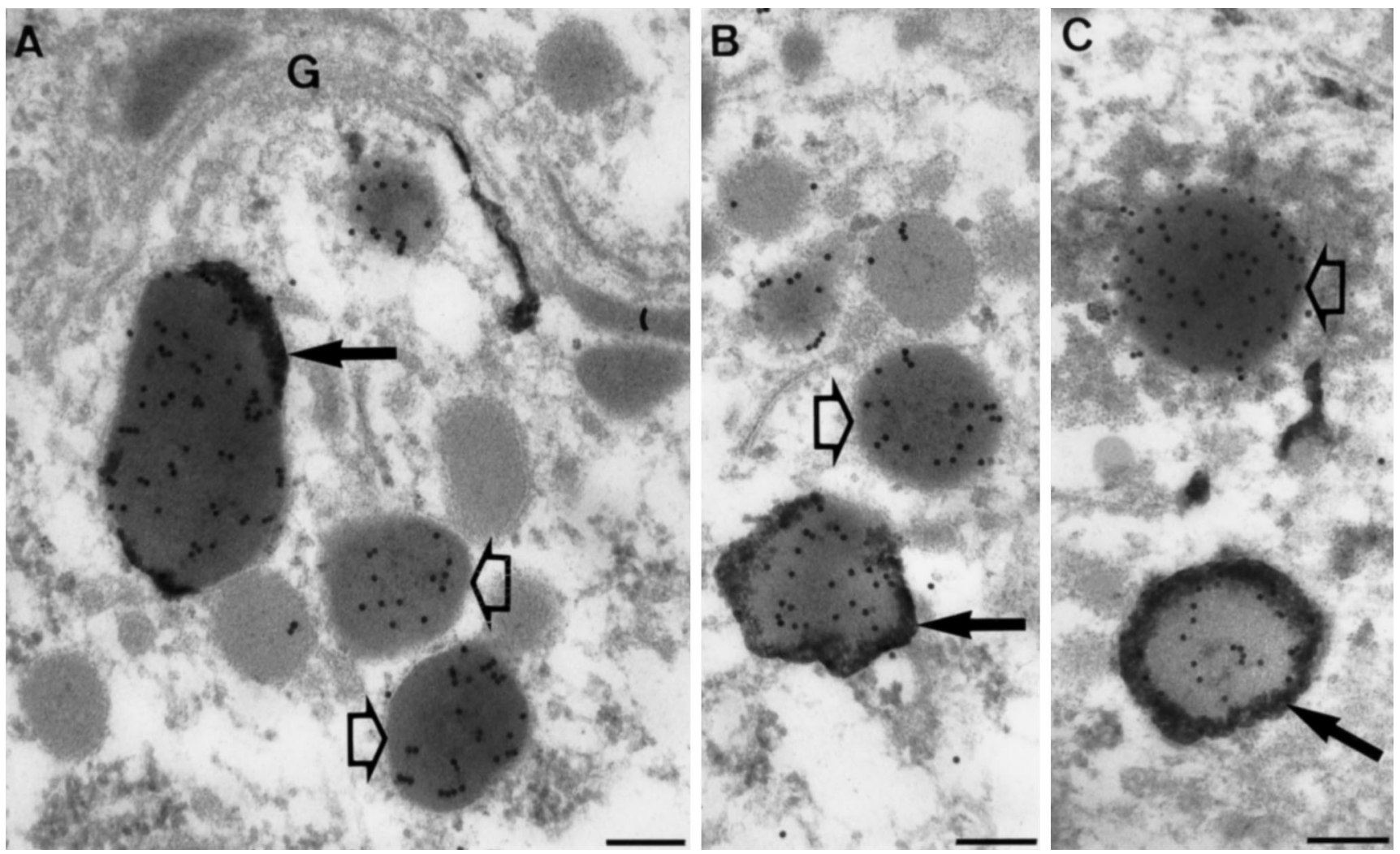

Figure 7. Type I neurons in which lysosomal acid phosphatase (AP) was visualized by enzyme cytochemistry (dense reaction product) and N-terminal peptide by immunogold labeling. LEG positive for AP (bold arrows) were found near the Golgi $(A)$ and more peripherally $(B, C)$. In some AP-positive LEG, the N-terminal peptide label was decreased $(C)$. LEG without AP reaction product (open arrows) were also seen. $G$, Golgi. Scale bars, $0.1 \mu \mathrm{m}$.

their subsequent degradation in LEG as a mechanism to prevent secretion of potentially active peptides by the constitutive secretory pathway.

LEG as defined in this paper have only been described in detail, as far as we know, in the ELH-producing cells of Lymnaea and Aplysia, but may well have a wider distribution. For example, the gonadotropin hormone (GTH)-secreting cells of the African catfish Claria gariepinus contain granules with a LEG-like morphology and a condensed protein content. Recent immunoelectron microscopy revealed that these bodies specifically contain the $\beta$-subunit of GTH, whereas the LDCV contain both $\alpha$ - and $\beta$-GTH (Sharp-Baker et al., 1995). Moreover, it was shown that the $\beta$-GTH-rich granules are post-Golgi compartments, which obtain lysosomal enzymes and degrade their content.

Both Lymnaea and Aplysia proELH are multipeptide precursors (Scheller et al., 1988; Vreugdenhil et al., 1988) and share an overall sequence identity of up to $70 \%$ (Nagle et al., 1989). Surprisingly, there seem to be at least two post-translational strategies to modulate the output from proELH. In Aplysia, a single neuron type generates two populations of LDCV (Sossin et al., 1990a), whereas in Lymnaea two neuron types each make a single set of LDCV. Moreover, in Aplysia it was suggested that formation of type II-like LDCV requires cleavage of proELH in the Golgi/TGN and subsequent sorting of the two intermediates by temporal condensation or binding to a putative sorting receptor (Kreiner et al., 1988; Sossin et al., 1990), whereas our data suggest that type II LDCV are formed when proELH is not cleaved in the Golgi/TGN (Fig. 8). Interestingly, the outcome of both strategies is essentially the same, because both species re-

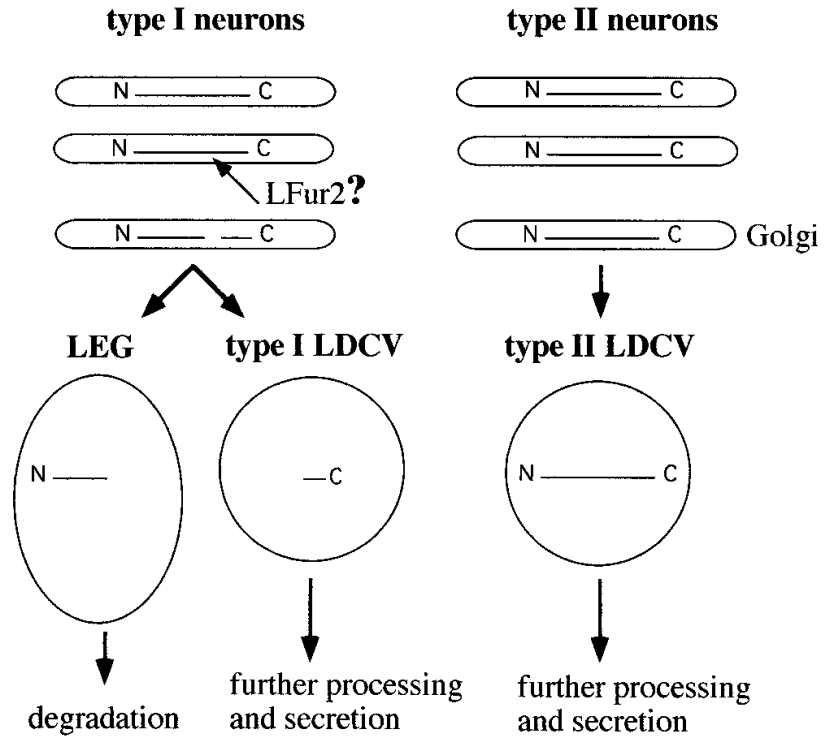

Figure 8. Putative model of how differential processing of proELH may account for the differential sorting of $\mathrm{N}$-terminal peptide in type I and type II neurons. In type I neurons, the C-terminal part of proELH is sorted into LDCV, whereas the N-terminal intermediate is targeted to LEG and degraded. In type II neurons, both C-terminal proELH-derived and $\mathrm{N}$-terminal proELH-derived peptides are found in LDCV. A possible explanation for the occurrence of $\mathrm{N}$-terminal peptides in LDCV of type II neurons would be that they are still attached to the $\mathrm{C}$-terminal part at the time of LDCV formation. The finding that the endoprotease LFur2 is solely expressed in type I neurons is in line with this hypothesis. 


\section{Lfur1}

\section{Lfur2}
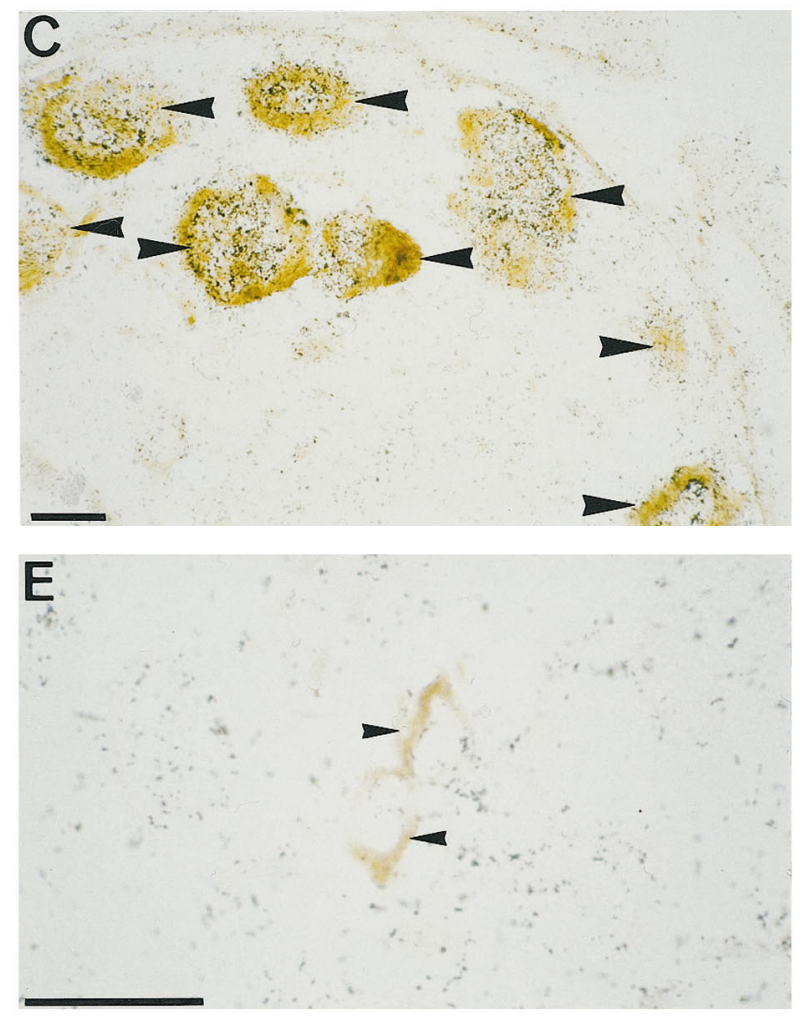

\section{LPC2}

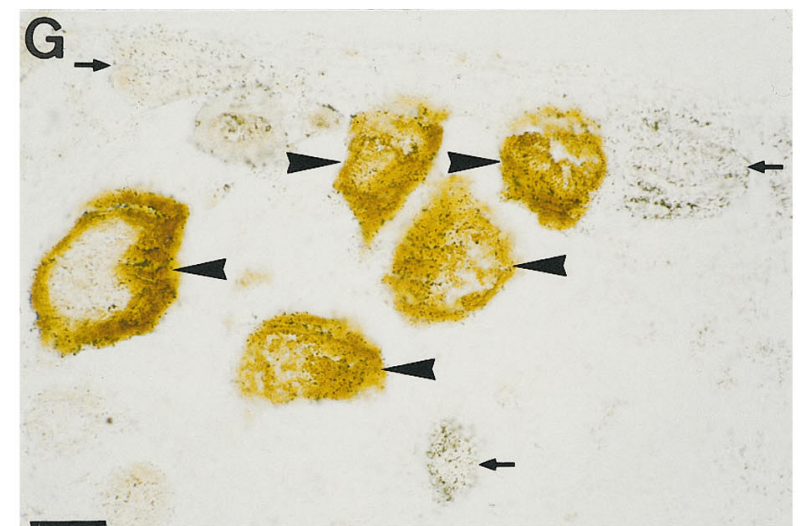

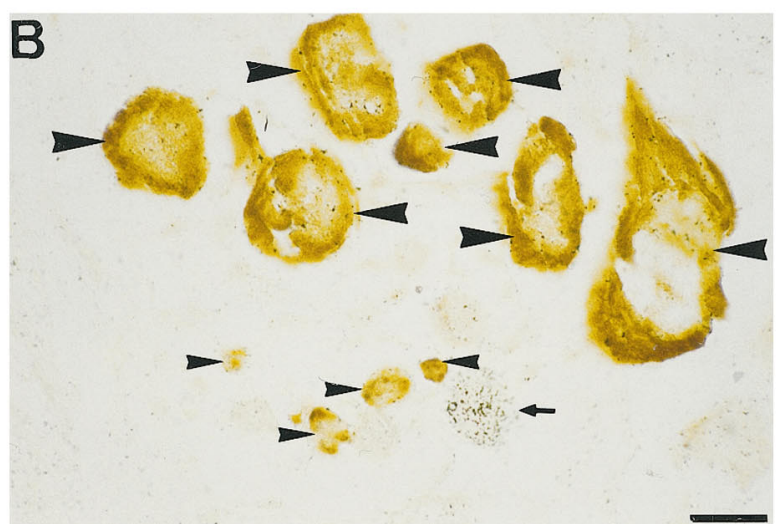
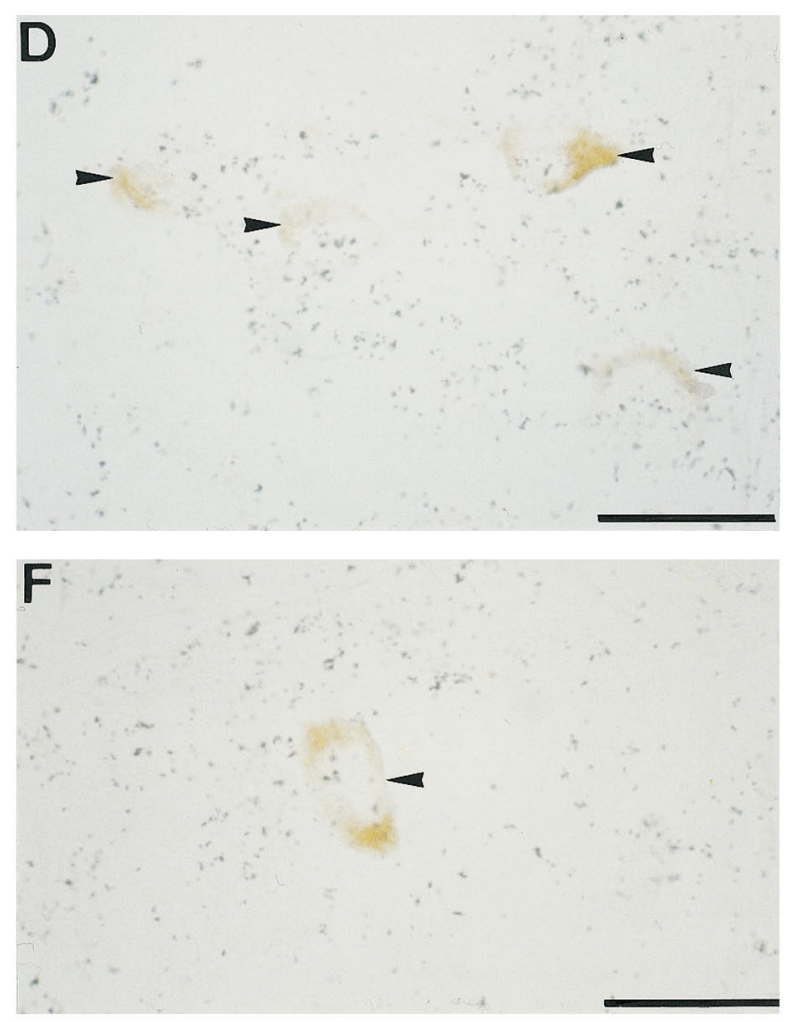

H

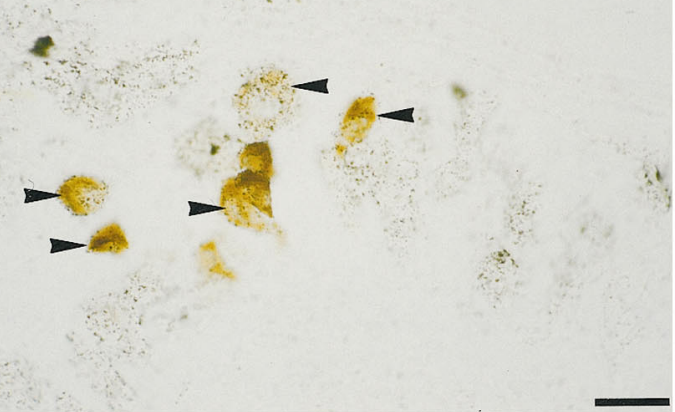

Figure 9. Expression of Lfur1 $(A, B)$, Lfur2 $(C, D)$, and LPC2 $(G, H)$ mRNA, as assessed by radioactive cRNA in situ hybridization (black silver grains). Type I (large arrowheads) and type II (small arrowheads) neurons were identified by ELH immunocytochemistry (brown reaction product). $A$, $B$, Lfur1 mRNA was only detected in non-ELH-producing neurons (small arrow). $C-F$, LFur2 mRNA was readily detectable in type I neurons (C). In type II neurons, of which high-magnification views are shown in $D-F$, labeling did not exceed background levels. $G, H$, LPC2 mRNA could be detected in both type I and type II neurons. Non-ELH-producing neurons that express LPC2 are indicated by small arrows. Scale bars, $25 \mu \mathrm{m}$. 
lease only the LDCV with a low amount of N-terminal peptides into the circulatory system.

The formation of both LDCV and LEG in Lymnaea type I neurons must be preceded by an endoproteolytic cleavage of the prohormone. Membrane-bound, furin-like endoproteases, which are predominantly localized in the TGN (Bosshart et al., 1994; Molloy et al., 1994), cleave proproteins at the consensus tetrabasic site Arg-X-Lys/Arg/X-Arg (Bresnahan et al., 1990; Hosaka et al., 1990; Van de Ven et al., 1990; Wise et al., 1990; Korner et al., 1991b). By contrast, soluble PC cleave precursor proteins after pairs of basic residues (mostly Arg-Arg and Lys-Arg) (Seidah et al., 1990, 1991; Smeekens and Steiner, 1990; Benjannet et al., 1991; Korner et al., 1991a; Nakayama et al., 1991; Smeekens et al., 1991). The cleavage site used first in Lymnaea proELH, Arg-SerArg-Arg ${ }^{180-183}$ (Li et al., 1994), fulfills all the requirements for the consensus sequence R-X-R/L-R for furin (Hosaka et al., 1991; Watanabe et al., 1992). An extensive search in the Lymnaea CNS revealed the presence of three subtilisin-like endoprotease isoforms: two furin-like proteins and a PC-like protein (Smit et al., 1992, 1994) (our unpublished observations). Because we have now found that Lfur2 is the only endoprotease that is exclusively expressed in type I neurons, we consider this protein a likely candidate to mediate the initial cleavage of proELH in these cells. However, in vitro processing studies are required to formally prove this hypothesis.

Based on its homology with vertebrate PC2, we predict that LPC2 will be incorporated into LDCV, where it will be responsible, at least partially, for the further processing of proELH (Davidson et al., 1988; Christie et al., 1991; Kirchmair et al., 1992). The lack of furin-like proteins in type II neurons, whereas LPC2 is present, suggests that in these cells processing will start after incorporation of proELH into LDCV. This would favor a model in which the N-terminal peptides are sorted to LDCV, because they are still attached to the C-terminal part of the prohormone, which contains all information for correct sorting (Fig. 8). This scenario would be in agreement with heterologous expression studies on Aplysia proELH. When Aplysia ELH is expressed in AtT20 cells, only the C-terminal part is targeted to the regulated secretory pathway (Jung et al., 1993). However, if the site ArgArg-Lys-Arg is deleted, which represents the initial cleavage site of Aplysia ELH that in vivo is used by a furin-like protease (Chun et al., 1994), the entire noncleaved prohormone ends up in LDCV.

In conclusion, our data have shown that the two proELHproducing neurons of Lymnaea sort different sets of prohormonederived peptides to LDCV. In cells that use only part of the newly synthesized peptides, a possible secretion of the nonsorted, but bioactive, peptides via the constitutive pathway is prevented by their segregation into degradative LEG, via a differential condensation/retention mechanism. Essential for this selective degradation is an early cleavage and sorting of the resulting $\mathrm{N}$ - and C-terminal intermediates. Our data suggest that a cell typespecific expression of a furin-like endoprotease is responsible for this cleavage.

\section{REFERENCES}

Barka R, Anderson PJ (1962) Histochemical methods for acid phosphatase using hexazonium pararosanilin as coupler. J Histochem Cytochem 10:741-753.

Benjannet S, Rondeau N, Day R, Chretien M, Seidah NG (1991) PC1 and $\mathrm{PC} 2$ are proprotein convertases capable of cleaving proopiomelanocortin at distinct pairs of basic residues. Proc Natl Acad Sci USA $88: 3564-3568$.
Bresnahan PA, Leduc R, Thomas L, Thorner J, Gibson HL, Brake AJ, Barr PJ, Thomas G (1990) Human fur gene encodes a yeast KEX2-like endoprotease that cleaves pro-beta-NGF in vivo. J Cell Biol 111:2851-2858.

Bosshart H, Humphrey J, Deignan E, Davidson J, Drazba J, Yuan L, Oorschot V, Peters PJ, Bonaficino JS (1994) The cytoplasmic domain mediates the localization of furin to the trans-Golgi network en route to the endosomal/lysosomal system. J Cell Biol 126:1157-1172.

Chun JY, Korner J, Kreiner T, Scheller RH, Axel R (1994) The function and differential sorting of a family of Aplysia prohormone processing enzymes. Neuron 12:831-844.

Christie DL, Batchelor DC, Palmer DJ (1991) Identification of kex2related proteases in chromaffin granules by partial amino acid sequence analysis. J Biol Chem 266:15679-15683.

Davidson HW, Rhodes CJ, Hutton JC (1988) Intraorganellar calcium and $\mathrm{pH}$ control proinsulin cleavage in the pancreatic B cell via two site specific endopeptidases. Nature 333:93-96.

Dunn WA (1994) Autophagy and related mechanisms of lysosomemediated protein degradation. Trends Cell Biol 4:139-143.

Farquhar MG (1969) Lysosome function in regulating secretion: disposal of secretory granules in cells of the anterior pituitary gland. In: Lysosomes in biology and pathology, Vol 2 (Dingle JT, Fell HB, eds), pp 462-482. Amsterdam: North Holland.

Fisher JM, Sossin W, Newcomb R, Scheller RH (1988) Multiple neuropeptides derived from a common precursor are differentially packaged and transported. Cell 54:813-822.

Fumagalli G, Zanini A (1985) In cow anterior pituitary, growth hormone and prolactin can be packed in separate granules of the same cell. J Cell Biol 100:2019-2024.

Garreau de Loubresse N, Gautier MC, Sperling L (1994) Immature secretory granules are not acidic in Paramecium: implications for sorting to the regulated pathway. Biol Cell 82:139-147.

Gautier MC, Garreau de Loubresse L, Madeddu L, Sperling L (1994) Evidence for defects in membrane traffic in Paramecium secretory mutants unable to produce functional storage granules. J Cell Biol 124:893-902.

Hashimoto S, Fumagalli G, Zanini A, Meldolesi J (1987) Sorting of three secretory proteins to distinct secretory granules in acidophilic cells of cow anterior pituitary. J Cell Biol 105:1579-1586.

Hosak M, Nagahama M, Kim WS, Watanabe T, Hatsuzawa K, Ikemizu J, Murakami K, Nakayama K (1991) Arg-X-Lys/Arg-Arg motif as a signal for precursor cleavage catalyzed by furin within the constitutive secretory pathway. J Biol Chem 266:12127-12130.

Huang XF, Arvan P (1994) The insulin-containing secretory granule core is formed in immature B-granules. J Biol Chem 269:20838-20844.

Huang XF, Arvan P (1995) Intracellular transport of proinsulin in pancreatic B-cells: structural maturation probed by disulfide accessibility. J Biol Chem 270:20417-20423.

Jung LJ, Kreiner T, Scheller RH (1993) Expression of mutant prohormones in AtT-20 cells: the relationship between prohormone processing and sorting. J Cell Biol 121:11-21.

Kelly R (1993) Storage and release of neurotransmitters. Cell 72:43-53.

Kirchmair R, Egger C, Gee P, Hogue-Angeletti R, Fischer-Colbrie R, Laslop A, Winkler H (1992) Differential subcellular distribution of PC1, PC2 and furin in bovine adrenal medulla and secretion of PC1 and PC2 from this tissue. Neurosci Lett 143:143-145.

Korner J, Chun J, Harter D, Axel R (1991a) Isolation and functional expression of a mammalian prohormone processing enzyme, murine prohormone convertase 1. Proc Natl Acad Sci USA 88:6834-6838.

Korner J, Chun J, O'Bryan L, Axel R (1991b) Prohormone processing in Xenopus oocytes: characterization of cleavage signals and cleavage enzymes. Proc Natl Acad Sci USA 88:11393-11397.

Kreiner T, Sossin W, Scheller RH (1986) Localization of Aplysia neurosecretory peptides to multiple populations of dense core vesicles. J Cell Biol 102:769-782.

Kuliawat R, Arvan P (1994) Distinct molecular mechanisms for protein sorting within immature secretory granules of pancreatic B-cells. J Cell Biol 126:77-86.

Li KW, Jimenez CR, van Veelen PA, Geraerts WPM (1994) Processing and targeting of a molluscan egg-laying peptide prohormone as revealed by mass spectrometric peptide fingerprinting and peptide sequencing. Endocrinology 134:1812-1819.

Marzella L, Glaumann H (1987) Autophagy, microautophagy and crinophagy as mechanisms for protein degradation. In: Lysosomes, their role in protein breakdown, pp 319-358. London: Academic. 
Molloy SS, Thomas L, van Slyke JK, Stenberg PE, Thomas G (1994) Intracellular trafficking and activation of the furin proprotein convertase: localization to the TGN and recycling from the cell surface. EMBO J 13:18-33.

Nagle GT, Painter SD, Blankenship JE (1989) Post-translational processing in model neuroendocrine systems: precursors and products that coordinate reproductive activity in Aplysia and Lymnaea. J Neurosci Res 23:359-370.

Nakayama K, Hosaka M, Hatsuzawa K, Murakami K (1991) Cloning and functional expression of a novel endopeptidase involved in prohormone processing at dibasic sites. J Biochem (Tokyo) 109:803-806.

Roubos EW (1976) Neuronal and non-neuronal control of the neurosecretory caudodorsal cells of the freshwater snail Lymnaea stagnalis. Cell Tissue Res 168:11-31.

Scheller RH, Jackson JF, McAllister LB, Rothman BS, Mayeri E, Axel R (1988) A single gene encodes multiple neuropeptides mediating a stereotyped behavior. Cell 32:7-22.

Schmidt ED, Roubos EW (1989) Quantitative immunoelectron microscopy and tannic acid study of dynamics of neurohaemal and nonsynaptic peptide release by the caudodorsal cells of Lymnaea stagnalis. Brain Res 489:325-337.

Seidah NG, Gaspar L, Mion P, Marcinkiewicz M, Mbikay M, Chretien M (1990) cDNA sequence of two distinct pituitary proteins homologous to Kex2 and furin gene products: tissue-specific mRNAs encoding candidates for pro-hormone processing proteinases [published erratum appears in DNA Cell Biol (1990) 9:789]. DNA Cell Biol 9:415-424.

Seidah NG, Marcinkiewicz M, Benjannet S, Gaspar L, Beaubien G, Mattei MG, Lazure C, Mbikay M, Chretien M (1991) Cloning and primary sequence of a mouse candidate prohormone convertase PC1 homologous to PC2, Furin, and Kex2: distinct chromosomal localization and messenger RNA distribution in brain and pituitary compared to $\mathrm{PC} 2$. Mol Endocrinol 5:111-122.

Sharp-Baker HE, Peute J, Diederen HB, Brokken L (1995) Origin and destination of globules and irregular masses in the gonadotropin cells from the pituitary of the African catfish, Clarias gariepinus: a morphological study. Cell Tissue Res 289:113-122.

Slot JW, Geuze HJ, Weerkamp AJ (1988) Localization of macromolecular components by application of the immunogold technique on cryosectioned bacteria. Methods Microbiol 20:211-236.

Slot JW, Geuze HJ, Gigengack S, Lienhard James DE (1991) Immunolocalization of the insulin regulatable glucose transporter in brown adipose tissue of the rat. J Cell Biol 113:123-135.

Smeekens SP, Steiner DF (1990) Identification of a human insuloma cDNA encoding a novel mammalian protein structurally related to the yeast dibasic processing protease Kex2. J Biol Chem 265:2997-3000.

Smeekens SP, Avruch AS, LaMendola J, Chan SJ, Steiner DF (1991) Identification of a cDNA encoding a second putative prohormone convertase related to PC2 in AtT20 cells and islets of Langerhans. Proc Natl Acad Sci USA 88:340-344.

Smit AB, Spijker S, Geraerts WPM (1992) Molluscan putative prohormone convertases: structural diversity in the central nervous system of Lymnaea stagnalis. FEBS Lett 312:213-218.

Smit AB, Spijker S, Nagle GT, Knock SL, Kurosky A, Geraerts WPM (1994) Structural characterization of a Lymnaea putative endoprotease related to human furin. FEBS Lett 343:27-31.
Smit AB, Spijker S, van Minnen J, Burke J, de Winter F, van Elk R, Geraerts WPM (1996) Expression and characterization of molluscan insulin-related peptide VII from the mollusc Lymnaea stagnalis. Neuroscience 70:589-596.

Sossin W, Sweet-Cordero A, Scheller RH (1990a) Dale's hypothesis revisited: different neuropeptides derived from a common prohormone are targeted to different processes. Proc Natl Acad Sci USA 87:4845-4848.

Sossin WS, Fisher JM, Scheller RH (1990b) Sorting within the regulated secretory pathway occurs in the trans-Golgi network. J Cell Biol 110:1-12.

Steiner DF (1991) Prohormone convertases revealed at last. Curr Biol 6:375-377.

Sweet CA, Fisher JM, Sossin W, Newcomb R, Scheller RH (1990) Subcellular fractionation of prohormone processing products in the bag cell neurons. J Neurochem 55:1933-1941.

Tooze J, Kern HF, Fuller SD, Howell KE (1989) Condensation-sorting events in the rough endoplasmic reticulum of exocrine pancreatic cells. J Cell Biol 109:35-50.

Tooze SA, Chanat E, Tooze J, Huttner WB (1993) Secretory granule formation. In: Mechanisms of intracellular trafficking and processing of proproteins (Peng Loh Y, ed), pp 157-178. Boca Raton, FL: CRC.

Valetti C, Grossi CE, Milstein C, Sitia R (1991) Russell bodies: a general response of secretory cells to synthesis of a mutant immunoglobulin which can neither exit from, nor be degraded in, the endoplasmic reticulum. J Cell Biol 115:983-994.

Van Heumen WRA, Roubos EW (1991) Immuno-electron microscopy of sorting and release of neuropeptides in Lymnaea stagnalis. Cell Tissue Res 264:185-195.

Van Heumen WRA, Broers-Vendrig CM, Roubos EW (1992) Light and electron microscopic immunocytochemical demonstration of synthesis, storage, and release sites of the neuropeptide calfluxin in Lymnaea stagnalis. Gen Comp Endocrinol 87:361-368.

Van Minnen J, van de Haar C, Raap AK, Vreugdenhil E (1988) Localization of ovulation hormone-like neuropeptide in the central nervous system of the snail Lymnaea stagnalis by means of immunocytochemistry and in situ hybridization. Cell Tissue Res 251:477-484.

Van de Ven WJM, Voorberg J, Fontijn R, Pannekoek H, van de Ouweland AMW, Van Duijnhoven JLP, Roebroek AJ, Siezen RJ (1990) Furin is a subtilisin-like proprotein processing enzyme in higher eukaryotes. Mol Biol Rep 14:265-275.

Vreugdenhil E, Jackson JF, Bouwmeester T, Smit AB, van Minnen J, van Heerikhuizen H, Klootwijk J, Joosse J (1988) Isolation, characterization and evolutionary aspects of a cDNA encoding multiple neuropeptides involved in the stereotyped egg-laying behaviour of the freshwater snail Lymnaea stagnalis. J Neurosci 8:4184-4191.

Watanabe T, Nakagawa T, Ikemizu J, Nagahama M, Murakami K, Nakayama K (1992) Sequence requirements for precursor cleavage within the constitutive secretory pathway. J Biol Chem 267:8270-8274.

Wise RJ, Barr PJ, Wong PA, Kiefer MC, Brake AJ, Kaufman RJ (1990) Expression of a human proprotein processing enzyme: correct cleavage of the von Willebrand factor precursor at a paired basic amino acid site. Proc Natl Acad Sci USA 86:9378-9382. 